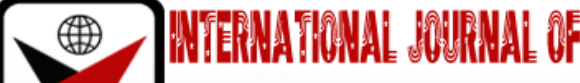

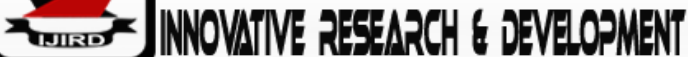

ISSN 2278 - 0211 (Online)

\section{Women in Politics: Implications for Credibility of Future Democratic Governance}

\begin{tabular}{|c|}
\hline Dr. Kwon-Ndung, Linda \\
Tenure Staff, Department of Political Science, \\
Federal University Lafia (Fulafia), Nigeria \\
Dr. Atsiya, Godiya Pius \\
Lecturer, Department of Political Science, \\
Nasarawa State University Keffi, Nigeria
\end{tabular}

\begin{abstract}
:
This paper interrogates women's participation in politics against the background of the 2019 general elections. The paper utilized theories on descriptive representation to buttress submissions on the need to promote women's involvement in the democratic process. Secondary method is used to generate data from extant literature for this work. Specifically, the influence of certain socio-cultural, economic and political factors that account for women's low participation and representation in governance is examined. Findings from the study revealed that while some African countries in the likes of Rwanda, Senegal, South Africa seems to be making giant strides and great progress in the political sphere, Nigeria has achieved little progress with worrisome results recorded during the just concluded 2019 general elections. The work finds that unequal political representation in Nigeria is the bane of socio-economic development hampering the nation's development practices among other things. The paper recommends a careful paradigm shift in terms of the over-bearing roles of men in the Nigeria political climate to strict compliance and practical implementation of international best practices as prescribed by the United Nations Organization as well as other relevant lawsto include gender mainstreaming which involves making the concerns and experiences of women and men an integral component of the design, implementation, monitoring and evaluation of policies and programmes in all development processes so that women and men can benefit equally.
\end{abstract}

Keywords: Gender, politics, political participation, election, democracy

\section{Introduction}

Gender mainstreaming has become one of the most popular calls globally today. Communities both local and international have come to realize the central roles exercised by women in societal progress generally. Women's roles are being increasingly noticed in the overall political development of the global community. The pivotal roles exercised by women political leaders in various parts of the world today can no longer be overlooked. Adadu\& Kwon-Ndung (2019) reports the very imposing presence of Angela Merkel of the Germany, the very push-up efforts of Hillary Clinton in the United States politics, the very dogged fight put forward by Theresa May in the British -EU Brexit saga along with the presence of Erna Soberg as Prime Minister of Norway and the role of Mrs. Ellen Johnson Sirleaf in stabilizing democracy in Liberia attests to the strong role of women in democratic politics

Nigeria's electoral epoch began during the colonial period which according to Udegbe (1998) was characterized by women disenfranchisement and massive erosion of their political power. The marginalization of the Nigerian women during the colonial period was because of the nature of colonial constitutions, which articulated, and determined the country's electoral process. Specifically, Nigerian's electoral process started in 1922, when the colonial government under Sir Hugh Clifford introduced the electoral principle in the country. This was contained in the 1922 constitution. The constitution however excluded all women and most men from electoral process by providing for the election of only four adult male politicians, three from Lagos and one from Calabar on a qualified franchise of one-year residency and a gross annual income of $100 £$ into the largely appointed central Legislative Council in Lagos (Bamidele\&Ikubaje, 2004; Akinboye\&Anifowose 1999).

Based on the elective principle of 1922 constitution, elections were held in 1923 for the first time in Nigeria's history.This was followed by elections every five years in 1928, 1933 and 1938. According to Akanji (2013) the impact of the elective principle was far reaching including establishment of political parties by Nationalist such as HerbetMacauley's Nigerian National Democratic Party (NNDP) and the Nigerian Youth Movement (NYM) formerly known as theLagos Youth Movement formed by nationalists such as Ernest Ikoli, Samuel Akinsanya, J.C. Vaughan and H.O. Davies (Ngou 1989; Dare, 1989). This was the beginning of party politics in Nigeria which the NNDP and NYM dominated the political scene until the emergence of other political parties from 1940's onward. The 1922 election engendered electoral politics, but it was 
defective in several ways which included a denial of women the right to vote and be voted for. Women across the country were excluded from voting during all elections that were conducted based on the 1922 constitution (ERC, 2008). The 1946 constitution, equally excluded women from election and therefore no woman was able to contest and vote in elections between 1946 and 1951. The 1951 constitution similarly denied women opportunity to vote and be voted for. The indirect elections (the electoral college system that was introduced in 1951 was such that a village constituted an electoral college where only tax paying adult males chose one of their members to represent males at the district level and upwards. Given the nature of the indirect electoral system women were disenfranchised and unable to participate in the electoral process.

Theinvolvement of women in politics varies throughout the world and their participation in politics and the democratic process has become an integral part of contemporary discourse on development and governance. However, in spite of the clamor for women's political empowerment by international organizations, research consistently shows that in many parts of the world women still linger on fringes of politics such as participation in government structures and the democratic process(Ogbogu, 2012).

The situation is more worrisome when one notes that the experience does not exclude the account of developed world where the capacity of women has not only been enhanced economically and socially but that cultural barriers as found in less developed countries are virtually non-existence.Adadu\&Kwon-Ndung(2019) reports that apart from Rwanda, Sweden and Canada who are high performers on the role of women in political activities of their countries, most countries in the developed world are under performing in this regard, and this includes, the United States which in ranked 104 out 190 countries for the number of women in the congress with 83 out 435 and the senate with 21 out of 100 members (Jezard, 2017).

In Nigeria, women constitute 49.3 percent of Nigeria's population according to World Bank's report and 51 percent of the voting population (Ofong, 2002).Statistics show that overall political representation by women in government is less than 7 percent Adadu\& Kwon-Ndung,(2019). This is a far cry from the 30 percent by the Beijing platform of Action which Nigeria is a signatory. This is despite the massive turnout of women in elections in Nigeria, the 2019 elections inclusive where only 62 women won elections out of 2,970 who contested elections at different levels and this represent $4.17 \%$ of elected officials which also represent a decline from 2015 elections where 5.5\% was recorded.

\section{Theoretical Issues}

Arguments on women's participation in politics abound in the literature. Most Scholarly studies on the issue of political representation of women focus on four main dimensions: formalistic, symbolic, descriptive, and substantive (Pitkin, 1967; Schwindt-Bayer and Mishler, 2005). The descriptive model of political participation is adopted for the theoretical analysis of this paper. This model tends to critically address the question as to whether the election of more women into political and leadership positions will ensure greater representation and participation of the group.

Advocates of this school stressed the importance of a resembling composition between the representatives and the represented to ensure that the representatives would act the way the represented would. Underlying the support for descriptive representation is the assumption that numbers matter: an increase in women's descriptive representation will generally translate to an increase in their substantial representation, especially on women's policy issues. Four major claims are listed by advocates of descriptive representation to include: the justice claim, the women's interest claim, the rights claim, and the added value claim.

The Justice Claim argument for gender parity in political representation centers on the question of justice and fairness. Supporters of the argument emphasize numerical strength in making the case. The opined that since women constitute half of the world's population, they should be given the same level of equality in political representation. Proponents of descriptive representation argue that if there were no challenges to women's political representation, one would expect elective and appointment positions of leadership to be randomly distributed between both males and females and across other social groups that constitute the society. In a nutshell, justice claim requires the elimination of all forms of intentional or structural obstacles to women's representation.

The second argument for increased women's political representation states that there are particular needs and interests (strategic and specific needs) that arise from women's experience that will not be adequately addressed in a male-dominated polity. This argument is grounded on the notion that women occupy a distinct position in the society considering that they are typically concentrated mainly in lower-paid jobs, and that they carry the primary responsibility for the unpaid work of caring for others. This perspective, therefore, claims that addressing women's representation requires, in addition to universal suffrage, gender parity among those elected to office.

The rights claim argument states that providing opportunities for women and men to participate equally in all political processes is a human right obligation, and that respect for these rights brings greater democratic legitimacy and increases the likelihood of inclusive governance. The rights argument is based on international human rights and genderequality standards endorsed by various states, which enshrine equal rights for women and men and promote gender equality, as well as the international standards and principles governing the functioning of democratic institutions.

The 1948 Universal Declaration of Human Rights (UDHR) protects "equal rights of men and women", including the right to participate in government. The Declaration lays the foundation for other international commitments in the area of women's rights. The most comprehensive articulation of these rights is contained in the 1979 United Nations (UN) Convention on the Elimination of All Forms of Discrimination against Women (CEDAW). The 1995 UN Beijing Declaration and Platform for Action expanded CEDAW by mandating the Member States to "take measures to ensure women's equal access to and full participation in power structures and decision-making." 
Interestingly, the United Nations Millennium Declaration, also known as the Millennium Development Goals (MDGs), adopted in 2000, with related objectives, which make up a global plan for the $21^{\text {st }}$ century, decided to "promote gender equality and the empowerment of women", and this objective is adjudged to be very important towards achieving the other seven Millennium Development Goals. In the same vein, the Sustainable Development Goals (SDGs), as successive programme that came after the Millennium Development Goals (MDGs), which was adopted in 2015, came up with 17 main objectives out of which the $5^{\text {th }}$ objective seeks to "achieve gender equality and the empowerment of all women and girls." Most women activists have capitalized on these international instruments to push their case for increased women's representation in political leadership positions.

The Added Value Claim Argument for gender equality in political representation has shifted from the justice, interest, and rights claims to a more realistic argument. It tries to convince individuals and organizations that do not accept the justice, interest, and rights arguments by appealing to their various interests. It, therefore, takes a bonus-based approach by persuading political parties and its leaders, to support the political participation of women. The idea here is that leaders are more likely to be convinced if they see that increased presence of women in political office can help parties compete more effectively and draw attention to the party's policy issues that may secure greater support from the electorate.

This approach is rooted in two main arguments: the "difference" argument, and the "pragmatic" or "utilitarian" argument (Lovenduski, 2005; Childs, Lovenduski and Campbell, 2005). The difference argument posits that women and men bring different perspectives, views and experiences to the table that can enrich political and policy and that only through full and fair representation will these differences be considered in political policy and decision-making. On the other hand, the "pragmatic" argument outlines the benefit parties stand to receive by including more women in their power structures. These benefits include greater electability, legitimacy, as well as the broader array of skills, knowledge and expertise that women bring.

\section{Gender and Electoral Reform 1999-2010}

Historical scrutiny of constitutions and electoral laws and processes in Nigeria are undeniably gender insensitive. Beginning from 1922, when the first constitution in Nigeria was made to the 1999 constitution as amended, which purportedly gave legitimacy to the Third Republic, aspirations and concerns of women, who represents majority of the population, have been undisputedly inadequate.

Afolabi(2013) reported that since the return of civilian rule in 1999, there was a lot of momentum gathered around the need for constitutional and electoral reforms. This development challenged the female gender in the country, with several women groups lending their voices to the electoral and constitutional reform discourse. Their active participation is dated back to the first attempt at reviewing the 1999 Constitution as amended by President Olusegun Obasanjo's administration in October 1999, when the first Presidential Committee was inaugurated to do a comprehensive constitutional and electoral review. The Committee had twenty-four members out of which four were women. However, the report submitted by the Committee had some gender friendly provisions, namely; a proposal that the Federal Character Commission be replaced with Equal Opportunities Commission with a more expanded and inclusive mandate; it also proposed that women should have a choice in claiming their own state of origin or their husband's in political arrangements, the third major amendment proposed by the Committee was the substitution of the word "sex" as it refers to the feminine in the Constitution with the word "gender". On political parties, it also included gender as one of the grounds for which discrimination in terms of membership of the Party shall not be permissible. Unfortunately, the report was later jettisoned.

After the re-election of President Obasanjo in 2003, he again convoked a National Political Reform Conference (NPRC) in 2005, to address the challenges of Nigeria's political system. Unfortunately, in terms of representation the conference did not attempt to give equal opportunities to all Nigerians. There were only 30 women out of about 400 delegates. Despite the obvious gender gaps in representation of women, the NPRC significantly mainstreamed gender issues in its outcomes. This attempt at political reforms also achieved very little.

Nigeria then went into the 2007 elections with a less gender friendly and a similar constitution with the electoral law adopted a year earlier in 2006. As it has been widely acknowledged, the 2007 elections were characterized by charges of irregularities, electoral malpractices, violence and various degrees of disruptions (Afolabi,2013)

One would then think that the Electoral Reform Committee (ERC) inaugurated by the late President, AlhajiUmaruYar' Adua on 28th August 2007 with the mandate to review and ensure quality and standard for general elections would address some of the pertinent issues of Nigeria's electoral democracy. The Committee, headed by a reputable retired Chief Justice of the Federation, Justice Muhammed Bello Uwais, went around the country taking memoranda and oral presentations from Nigerians. It also met several women groups agitating for the inclusion of women issues and concerns in the Committee's recommendation to the government. The Committee's recommendations have been adjudged laudable in the history of constitutional and electoral reforms in Nigeria.(Afolabi,2013) observed that the report of the Committee acknowledged the voices of women and their proposals for a gendered democracy and made some gender sensitive recommendations of the committee worthy of note. For example (i)on the composition of the Independent National Electoral Commission (INEC): it recommended that the Chairman and the Deputy should not be of the same gender and out of 6 geo-political representations two must be women. In addition, there should be a woman representative from the women's organization. ii) On Political Parties' Registration and Regulatory Commission, the ERC recommended that two out of six persons from the geo-political zonal representatives must be women. It also recommended further that the political associations should maintain $20 \%$ women in the membership of its governing bodies. iii) On enhancing internal democracy in the political parties: the ERC recommended that political parties should 
give more attention to the nomination of women and youths as candidates and ensure that women have equal access to leadership opportunities within party organizations. The report also recommended that political parties should nominate for the proportional representation at least $30 \%$ female candidates and $2 \%$ physically challenged candidates for legislative elections.

The ERC report was subsequently submitted to the National Assembly for consideration. The National Assembly has passed the 2010 Electoral law and has concluded the review of the constitution with little improvements on the gender question for instance, the only probable gender friendly proposal by the National Assembly was the new clause allowing for independent candidacy which was later thrown out by the state Houses of Assembly. This development shows the failure of the Nigerian state once again to put a legal framework in place to support a gender friendly electoral system.

\section{Historical Development of Nigerian Women in Politics}

The involvement of women in the governance of Nigeria started with the milestone reaction of the women in Aba in 1929 against the activities of the colonialists in Nigeria's Eastern region (Bakare,2002). The riot was a culmination of the reaction to the appointment of warrant chiefs and subsequent other obnoxious policies of the imperialist government.The riotstands out in history of women democratic struggle in the country. Other recorded feats achieved by the women folks included those exercised by Mrs. FumilayoRansome-Kuti, whose opposition to colonial taxation of women in 1947 became well known at the period, the activist role of HajiyaGamboSawaba and the key role she played among the three women who participated in her negotiation for Nigeria's independent and also fought tirelessly for the enfranchisement of Northern Nigerian women (Adadu, 2004, Azuike, 2005). Despite the roles played by HajiyaGamboSawaba in her political struggles and relentless efforts to reshape the Nigerian history,Northern Nigerian women were still not given the right to vote like their counterparts in the South until the 1979 constitution institutionalized this rights to vote (Sani 2001; cited in Azuike,2005).This was however contrary to the account of women in the southern Nigerian, who got voting right as far back as 1959(Azuike, 2005).

Furthermore, after independence in 1960 when party politics was used in Nigeria's political and governance processes, only a few women were actively involved in partisan politics. This clearly depicts the marginalization that started during colonial rule and became further intensified in the post-colonial Nigeria.Adadu (2004)reported that politics within the period has been largely dominated by men while the females only exercise subordinate roles in the processes. The performance of women in the colonial and post-colonial era was largely affected by the patriarchal societyof Nigeria. On this account, (Adadevoh, 2002. p16) stated thus;

The position of women in the patriarchal pre-colonial settings set the background for the present political quagmire in Nigeria for instance, in the epoch, power structures are highly patriachalized and only exceptional few members can venture into the public sphere of patriarchal politics.

The patriarchal nature of the society in Nigerian society reflects notjust in elective politics but also finds expressions in the various appointments into political positions as most communities in the country find themselves nominating more male members of their communities than their nominated female counterparts.

Governance since 1960 has been a male dominated affair. Women were incorporated into the political system as subordinates, ineffectual adjuncts to men. Thus, the nature of their incorporation reveals the persistence of male dominance and gender bias over time. In 1961, three women were elected into the Eastern House of Assembly. From 1960 to 1966, two women were voted to the Federal Senate. There were no female ministers at either federal or regional levels (Williams, 1997). The First Republic Senate, with 36 members, had only one female member, Mrs.WuraolaEsan, nominated by the Western Region. The House of Representatives with 312 members had none. Also, neither the federal government nor the three regional governments had women on their cabinets. Between 1961 and 1964, three women: Mrs. Margaret Ekpo, Mrs. Janet Mokelu and Mrs. Ekpo Young, won seats into the Eastern House of Assembly and Mrs. Beatrice Kerry joined Mrs. Esan in the Senate. Nigerian women fared slightly better under the six military regimes that lasted from 19661999(Akiyode-Afolabi\&Arogundade, 2003).

In the preface to independence and during the First Republic, parties nominated women as candidates for elections in constituencies where they had little chance of being elected (Okome, 2000). No woman was nominated as presidential or gubernatorial candidate. Some women were drafted as gubernatorial running mates, such as the People's Redemption Party (PRP) which nominated Bola Ogunbo as Aminu Kano's running mate. Four women contested for the 95seat Senate and all lost. Seventeen of the 2,000 contestants for the 450-seat Federal House of Representatives were women; three of them won. Forty- two out of the 5,000 contestants for State Houses of Assembly but only were women. Five of them won (Williams, 1997). During the transition to the Second Republic, there was a renaissance of "women's wing" in all the registered political parties. The women's wing had representation in the parties' national executive, but did not participate in policy-making caucuses. The positions that women held in the parties did not go beyond that of (one out of many) Vice-Chairpersons.

In the elections that ushered in the Second Republic in 1979, women did not fare any better. Only a handful of women contested elections at various levels, with none for the Presidency and Gubernatorial seats. Three women were elected into the 450 -member Federal House of Representatives with three women appointed into the Federal Cabinet. Also, there was appointment of one woman as Commissioner in each state. However, comparatively women's participation in party politics during this period improved from what it was during the First Republic. Women became party vicechairmen and at least one woman became running mate to a presidential candidate (Ezumah, 2000). A significant outcome of the 1983 General Elections was that it produced the first female Senator, Mrs. Franca Afegbua, and the only female out of the 95 members of Senate. The military took over power in 1983 and, as with earlier regimes; women were virtually non-existent in successive military administrations between 1983 and 1999. Evidently, the position of- women in 
governance and public service was largely dependent on the existing government. During the military regimes only, women whose husbands had positions were privileged and heard.

\section{From Political Dimness to Political Glare}

By 1999 when the Fourth Republic began, the number of women in political leadership positions in the country had increased. While such increase may not be entirely new, given the activities of the wives (the first ladies) of the military Heads of State of the country between 1985 and 1998, which raised public awareness about women issues (Akanji, 2009) and cases of elected and appointed women political office holders prior to 1999, the situation between 1999 and 2011 was noticeably different. More than ever in the political history of Nigeria, women won elections across the broad spectrum of federal, state and local government political offices during the elections of 1999,2003,2007 and 2011. This was although the electoral process - especially the use of universal adult suffrage, the nature of constituencies, the electoral system and the centralization of election administration - remained essentially as it was during the Second and Third Republics.

In the 1999 general elections into the federal legislatures (the Senate and the House of Representatives), five and twenty-nine women contested, for the 109- member Senate and the 360-member House of Representatives (OkoosiSimbine, 2007)). Of these, three (2.8\%) and thirteen (3.6\%) were elected, respectively to the Senate and the House of Representatives respectively.(Akanji,2009) reports that at the state legislative level, a total of 29 women contested for the 990-member 36 State Houses of Assembly, out of which 12(1.2\%) were elected and at the federal and state political executive levels, one female was elected Deputy Governor, though none was elected Governor, Vice President or President (Akanji,2009; Okoosi -simbine, 2007). From the 39\% of the women who contested in the elections, were elected. While this was an improvement, given the history of women exclusion from politics and elective offices in the country, the number of women who contested and won the elections when compared with that of men, was very low.

During the 2003 General Elections, however, women's involvement and performance at the federal and state levels improved as against 1999. For example, four (3.7\%) and twenty-one (6.1\%) women were elected to the Senate and House of Representatives, respectively in 2003, as compared to three (2.8\%) and thirteen(3.6\%) in 1999 for the same federal legislatures. For State Houses of Assemblies, thirty-nine (3.9\%) women, as opposed to twelve (1.2\%) in 1999, were elected in 2003 (Akanji, 2009). Notwithstanding, the performance of women in the 2003 General elections was still poor when compared with men and according to This Day (2007), several women participated in the elections.

Similarly, in the 2007 General elections, 628 of the 7,160 contestants were women (Akanji, 2009). While one female contested for the office of the President, 5 for Vice President, 14 for State Governors and 21 for Deputy Governors, 59 vied for the 109-member Senate, 150 for the 360-member House of Representatives and 358 for the 990-member State Houses of Assembly (Akanji, 2009). Of these figures, 5were elected Deputy Governors, nine (8.3\%) were elected into the Senate, twenty-seven (7.5\%) into the House of Representatives and fifty-four (5.5\%) into the state legislatures (Akanji, 2009). In terms of the number of female contestants and female elected officials, the 2007 figures, when compared with those of other elections before 1999, and between 1999 and 2003, showed an improvement. The climax of the increase in women representation in elective offices was the appointment of Patricia OlubunmiEtteh as the first female Speaker of the House of Representatives in 2007 (Olutayo, 2010), although female speakership of State Houses of Assembly was recorded between 1999 and 2007. These included Margaret Icheen (1999-2003) and TitiOseni (2003-2007) in Benue and Ogun states, respectively (Akanji, 2009). Yet it is imperative to note that the proportion of female candidates $(606$ of 9,820 , making only 6\%) (EU EOM, 2007) and elected female officials (15\% of total number of female contestants above) at the elections was still low. However, the electoral performance of women, and their involvement as contestants in the 2011 elections suffered a little setback, as shown by reduction in the number offemale contestants and elected female officials. During the election, women accounted for approximately 9 percent of all contestants to the National Assembly, 8.7 percent to the State Houses of Assembly, 3.7 percent for governorship, 17 percent for deputy governorship position, while there was only one female presidential candidate (out of twenty) (EU EOM, 2011). When compared with the period before 1999, the number of elected women in 2011 was high, but low in relation to elections between 1999 and 2007. For example, the results of the 2011 General Elections revealed that 7 women were elected to the Senate and 18 to the House of Representatives, while in 2007 they were 8 and 23,respectively (EU EOM, 2011). But like in previous elections, no woman was elected as president, vice president or state governor in the 2011 General Elections.

Overall, though some gains were recorded in women representation between 1999 and 2011, yet women in Nigeria remained politically marginalized and under-represented in elective offices and government, because the representation achieved was very marginal when compared with the number of men in elective offices during the same period and because the gains have not been sustained. This contradicted the goal of the country's National Gender Policy of building a just society devoid of discrimination $(F R N, 2008)$. Besides, the level of women representation so far achieved has been far below the gender instruments including the Convention on the Elimination of All Forms of discrimination against Women (CEDAW ratified in 1985. The important point, however is that the performance of women in political representation and participation improved from near dimness before 1999 to public glare after 1999, even though there was no major change when compared to how men fared. 


\begin{tabular}{|c|c|c|c|c|c|c|}
\hline S/N & Zones & Total Figure & Male & Female & \%of Male & \%of Female \\
\hline 1 & North Central & 1371 & 1255 & 116 & 91.5 & 8.5 \\
\hline 2 & North East & 1187 & 1137 & 50 & 95.8 & 4.2 \\
\hline 3 & North West & 2088 & 2039 & 49 & 97.7 & 2.3 \\
\hline 4 & South East & 1611 & 1420 & 1911 & 88.1 & 11.9 \\
\hline 5 & South Ossein & 1624 & 1454 & 170 & 89.5 & 10.5 \\
\hline 6 & South West & 2116 & 1787 & 329 & 84.5 & 15.5 \\
\hline 7 & Total & 9,997 & 9,092 & 90.5 & 90.9 & 9.1 \\
\hline
\end{tabular}

Table 1: Gender Ranking of Political Candidate and Women Political Participation by Zones Source: Akioye-Afolabi(2011) Cited in Arowolo(2015)

Table 1above shows how gender ranking and women participation in political contestation stood in the 2011 general elections. The statistics show clear dominance of the male candidates over the females generally. The best performance forfemale candidates out of 2116 candidates representing $15.5 \%$ stood for elections in the various elective positions. On the other hand, the least performance came from the North West with only as few as forty-nine female candidates out of 2088 representing a meager $2.3 \%$ were available to contest elections in the geo-political region. Overall only 905 female candidates contested elections out of the total 9,997 that contested elective positions in the 2011 election. This makes it only $9.1 \%$ of the total number as females.

The eightNational Assembly might have recorded marginal improvement over the previous ones but remained a far cry from the quota being canvassed at both national and international levels. The Houseof Representatives with 350 members in 2015 had only 15 females as elected members of the House.

\begin{tabular}{|c|c|c|c|c|}
\hline S/N & Name & State & Constituency & Party \\
\hline 1 & NnennaElendu -Ukeje & Abia & Bende & PDP \\
\hline 2 & NkirukaChidubemOnyejeocha & Abia & Isuikwuato/Umunneochi & PDP \\
\hline 3 & Azodo, Okunna & Anambra & Aguata & PDP \\
\hline 4 & SodagunoOmoni Festus & Bayelsa & Uvbia & PDP \\
\hline 5 & Evelyn OmavovoanOboro. & Delta & Etiti/ Uzo-Uwani & PDP \\
\hline 6 & Stella ObiageliNgwu & Enugu & Kaltungo/ Shongom & PDP \\
\hline 7 & Fatima Bello Binta & Gombe & Dukku/Nafada & APC \\
\hline 8 & AishatuJibrilDukku. & Gombe & Ajeromi-Ifelodun 1 & PDP \\
\hline 9 & Rita Orji & Lagos & Langtang North/Langtang South & PDA \\
\hline 10 & BeniButmaklar Lar & Borno & Gwoza/Damboa/Chibok & APC \\
\hline 11 & AsabeVilita Bashir & Kwara & Ekiti/Irepodun/Isin/Oke- Ero & APC \\
\hline 12 & OlufunkeAdedoyin & Asunedaade/Irewode/Isokan & APC \\
\hline 13 & Ayo HulayatOmidiran & Yobe & Gulani/Gujba/Damaturu/Tarmuwa & APC \\
\hline 14 & KhadijatBukar Ibrahim & Edo & Ovia South/ Ovia -West/ East & PDP \\
\hline 15 & Gabriella OmosedeIgbinedion & &
\end{tabular}

Table 2: Female Membership of the Nigerian House of Representative in 2015

Source: Official website of the National Assembly, (2015) cited in Arowolo, (2015)

The eight National Assembly Senate has only eight women as elected members. This is against 101 male members elected into the Senate. This figure leaves the female members with only 8.7 percent of the total membership of the Senate that stands at 109 members. Table 3 below shows a detailed breakdown of the female members with their parties as they stand at the end of the 2015 elections.

\begin{tabular}{|c|c|c|c|}
\hline S/N & Name & Senatorial District & Party \\
\hline 1 & Stella Oduah-Ogiemwonyi & Anambra North & PDP \\
\hline 2 & Uche, Ekunife & Anambra Central & PDP \\
\hline 3 & Rose OkojiOko & Cross River North & PDP \\
\hline 4 & Olujini, Abiodun & Ekiti South & PDP \\
\hline 5 & FatimatOlufunkeRaji-Rasaki & Ekiti Central & APC \\
\hline 6 & OluremiTinubu & Lagos Central & APC \\
\hline 7 & BintaMasiGarba & Adadmawa North & APC \\
\hline 8 & MonsuratSunmonu & Oyo Central & \\
\hline
\end{tabular}

Table 3: Female Membership of the Nigerian Senate in 2015 and their Parties

Source: (Arowolo D.E. 2015) Gender Politics and Sustainable Development in Nigeria

\section{Shrinking Public Space for Women in 2019 Elections}

Despite having 91 political parties suggesting a wider political space and also a well-enhanced avenue for electoral contestation in the 2019 elections, women did not do any better. Rather, the performance of the women folks became the worst ever in the fourth Republic. Onyeji (2019) reported the following highlights of poor performances of women in 2019 general elections in Nigeria.Only sixty-two women were elected into various positions in this dispensation and this 
represent $4.17 \%$ of elected officials which also indicates a decline from 2015 elections where $5.5 \%$ was recorded. Only two thousand, nine hundred and seventy women representing $11.36 \%$ contested elections in 2019 . Women were practically not ready for the presidential seat as all of those that made efforts to contest stepped down even though they were on the ballot up to the elections proper. The result of the National Assembly elections was quite revealing.Two hundred and thirty -five women representing $12.34 \%$ contested for Senate only $6.42 \%$ were elected. APC had 7 while PDP had 10. Senators BintaGarba and AbiodunOlujini both lost their seats in the Senate.

In the House of Representatives 533 women contested in the primaries of the major parties but only 31 candidates made it to the general elections. APC fielded 15 candidates while fielded PDP 16. Of all of these, only 11 got elected in the House of Representatives.

Of two hundred and seventy -five female deputy governorship candidates making $11.40 \%$, only 4 (in Enugu, Kaduna, Ogun and Rivers) were elected. This shows a decline from 6 women deputy governor in the 2015-2019 period.

Similarly, examining the electoral process and key role women had to play in the exercise perhaps apart from the three (3) out of the twelve (12) National commissioners of INEC that were women all indices of the 2019 election showed a disadvantaged outing for the women. This clearly show the marginalized and disadvantaged political space for the women, even the ministerial appointments that should have balanced up the gap indicate otherwise. For instance, the 43 ministerial nominees sent to the National assembly only 7 women were on the list which is equally worrisome and does not portray any intention of achieving the 35 percent affirmative action to meet up with global standards.

\section{Reasons for Poor Performance of Women in Nigerian Electoral Politics}

Okojo(1983) reported that the marginalization of the Nigerian women during the colonial period was because of the nature of colonial constitutions, which articulated, and determined the country's electoral process. Specifically, Nigerian's electoral process started in 1922, when the colonial government of Sir Hugh Clifford introduced the principle of election into the country. This was contained in the 1922 constitution. The constitution however excluded all women from participating in elections and this kind of laid the foundation of the marginalization of women in politics. Similarly, the issues of culture and religion are very serious in some societies. Some cultures still do not believe that women can be leaders while men are followers. Because of this,women who venture into politics are cultural deviants. In other words, patriarchy is not only entrenched in the society, but is also elevated to the state of policyAdadu\& Kwon-Ndung(2019). Women are expected to subordinate themselves to men. This is what cost Mrs. Margaret Icheen her seat as the speaker of Benue State House of Assembly. The seat was made so hot for her that she eventually resigned according to Boserup (1970).

Nzomo(1994) posited that the most significant barrier is the socio-cultural system of belief and myths, which informed the socialization process and the gendered education and training most men and women areexposed to from childhood. Accordingly, the sex-stereotypes and gender segregation in employment and allocation of roles in private and public life are fundamentally a product of the early socialization process, the indoctrination of the social environment. In this regard, many women's hang-ups and lack of confidence in their competence to execute public leadership roles arises from socialization for subordination. However, it is in the social culturalcontext that women's secondary role is most evident and has the most importantconsequences for the participation of women in politics.Similarly, (Onyeji,2019) reporting for Premium Times Newspapers (online) stated that the Centre for legislative engagement with YIAGA Africa, a Civil Society Organization listed poor funding, poor party structure and stereotyping against women as some of the challenges.

However, on a general note it was blamed on the overall political structure in the country. For instance, in the 2019 elections the two major political parties were clearly and particularly accused of not allowing enough space for women. There was also the intimidation of women within the political process or they were threatened to step down for stronger male candidates, or they were even screened out and therefore edged out of the process.Other factors such as large-scale violence, rigging and vote buying were also said to have played against the women in the electoral process and therefore worked against democratic consolidation. These factors give relevance to the tout theory which describes the political actors in Nigeria as ruthless, fearless and shameless.

\section{The Current Voyage of Women in the Electoral Process in Nigeria}

Reports from 2019 elections show a poor feat in terms of the number of women that showed up for contest and those that eventually made it as elected. Onyiji, (2019) points out this as the poorest since the commencement of the Fourth Republic in Nigeria. This appalling performance of women in the Nigerian democratic process clearly portrays the position of women in the voyage of the electoral process. This lack of inclusiveness is indeed worrisome and not capable of consolidating democracy to the extent of guaranteeing sustainable development. A cursory look at the role of women during the 2019 perhaps apart from the three (3) out of the twelve (12) national commissioners of INEC that were women, all indices of the 2019 election showed a disadvantaged outing for the women. This puts to question the thrust of the (National Gender Policy,2006.p17) which states that:

The overall goal is to build a just society devoid of discrimination, harness the full potentials of all social groups regardless of sex or circumstance, promote the enjoyment of fundamental human rights and protect the health, social, economic and political wellbeing of all citizens in order to achieve equitable rapid economic growth; evolve an evidence based planning and governance system where human, social, financial and technological resources are efficiently and effectively deployed for sustainable development. 
Apparently, this goal is yet to be fully achieved. There are clear cases of discrimination based on gender or sex, outright denial of the fundamental rights of women to be voted for exist but the right to vote is clearly tapped and used by the male politician to help them win election. This is quite unfortunate because the competences of women are usually not acknowledged. Little wonder the male politicians and even the government believe that at best they are only to be used to sing, dance during campaigns and cast their votes during elections. Government equally has not lived up to the expectation of women because it has failed to balance this gap by appointing women into positions of leadership to balance up the gap created by the failure to win elections because of the harsh political terrain.

\section{Conclusion}

The marginalization of the Nigerian women during the colonial period was as a result of the nature of colonial constitutions, which articulated, and determined the country's electoral process. Specifically,Sir Hugh Clifford introduced the elective principle into the country. This was contained in the 1922 constitution. The constitution however excluded all women and ever since then women have been squeezed in the electoral space. In fact, before the elections in 2019, the marginal improvement earlier recorded of women involvement in the political space was not good enough in the face of a more heightened voting strength considering the almost 50 percent of population of women in the country. Descending down from 5.5 percent in 2015 elections to 4.17 percent in the 2019 elections is indeed alarming and worrisome, this shows a poor performance of women in the electoral process particularly when the bellow is in the air for up to 35 percent. This obviously presents a male dominance in the democratic space and therefore a lowered inclusiveness as far as women performance in the democratic process. Patriarchy andSecurity issues around the electoral process have been raised along with other issues such as increasing role of money in Nigerian politics as causes for this poor performance of women in the electoral process. Other problems such asa weak political structure in the country together with a feeble institutional mechanism for a credible political process contribute immensely to the poor performance of women. Similarly, there is also the weak "self-belief" of women on themselves which has eroded the "can do spirit" among women. Apparently for Nigeria to attain the heights of country's like Rwanda, Canada and Sweden it requires conceited efforts in other to promote the inclusion of women in Nigeria's electoral process and ensure democratic consolidation.Similarly,affirmative action needs to be taken more seriously and not lip service during political campaigns to ensure that women play a more active role in the political process as is the case in Rwanda, Uganda, South Africa and Mozambique.The security around the electoral process must be enhanced and be more strategic for the purpose in other to ensure that all members of the society develop confidence in the process.Furthermore, money politics and the high electoral spending must be monitored and controlled to make the exercise open to alland political parties particularly the major ones must go beyond free forms and consider free tickets to encourage the women folks as a form quota system like the case in Rwanda to balance up the wide gap that exist between the participation of women and men in politics, in fact it can be constitutional as in Uganda Rwanda; Legislative as the case in many Latin America; or adopted by political parties as in South Africa and Momambique. This way the political voyage of women in Nigeria will be boosted and enhanced to guarantee greater participation of women in politics and engender development.

\section{References}

i. Adadu, Y.A. (2004). Women participation in Nigeria's democratic process and sustenance offamily life. In the Journal of Family DevelopmentVol.1(1). 44-56

ii. Adadu, Y.A. (2019). Electoral Violence in Nigeria: Causes and Implications. In Zoaka, Y.A.,

iii. Abdulhamid, S.O. \& Samson, A. A. (Eds). Public Policy and National Development in Nigeria: EssaysinHonour of Professor Sam Amdii. (pp361-370) Abuja: Joyce Publishers.

iv. Adadu, Y.A.\&Kwon-Ndung, L. (2019). Rethinking the role of women in the electoral process inNigeria.Paper presented at the NPSA $32^{\text {nd }}$ AnnualConference, Calabar. $22^{\text {nd }}-25^{\text {th }}$ July,2019.,

v. Akanji, 0.0.(2009).Women, gender question and political leadership in Nigeria:1999-2007.Ibadan Journal of the Social Sciences, Vol.7(2).52-68

vi. Akinboye, S.O.\&Anifowose,R.(1999).Nigerian government and politics in Anifowose,R\&Enemuo,F.C.(Eds)Elements of Politics (pp87-108).Lagos : Sam Iroanusi.

vii. Akioye-Afolabi (2011). Elections: Gender ranking of political candidates and other issues inWomen's Political Participation. Lagos: Women Advocates Research and Documentation Centre (WARDC)

viii. Arowolo, D. E (2015).Gender politics and sustainable development in Nigeria. InNasarawa

ix. Journal of Political Science. Vol3. (3). 129-137

x. Azuike, M.A. (2005). Women and governance: Four years of democracy in Nigeria. InGana

xi. A.T. \&Omelle, Y.B.C Democratic Rebirth in Nigeria, Vol.1. 1999-2003. Abuja Afrigov.

xii. Bamidele,I.\&Ikubaje,J.(2004). Position of citizens forum for constitutional reform on the1999 Constitution. Lagos: Report of Citizens Forum for Constitutional Reform(CFRC)

xiii. Boserup, E. (1970).Women in Economic Development. London: Allen andUnwin.

xiv. Electoral Reform Committee(ERC) (2008). Report of the Electoral Reform Committee, Vol.1:

xv. Ms,ain Report. Abuja: Federal Republic of Nigeria.

xvi. European Union Election Observation Mission(EU EOM). (2011) European Union Election

xvii. Observation Mission to Nigeria:Final Report on the 2011 General Elections. Available athttp://reliefweb.int/sites/files/resources/final-report-nigeria2011

enpdf\#page=7\&zoom=auto,0,532,[accessed 29 July2019] 
xviii. Federal Republic of Nigeria (FRN) (2006). National Gender Policy. Federal Ministry ofWomen Affairs and SocialDevelopment.

xix. Jezard, A. (2017). Women make up less than a quarter of the world's politicians-but thesecountries are bucking the trend. World Economic Forum.

xx. Mba, N. (1982) Nigeria women mobilized Berkeley: International and Area Studies. Universityof Berkeley

xxi. Mijah E.B.\&Adamu, A.A. (2018). Public perception of political parties and electoralprocess in Nigeria:Exploring the missing links. A Publication of Nigerian political Science Association

xxii. Ngou,C.M. (1989).The1959 elections and formation of the independence government. InEkeh,P.P,Patrick Dele Cole \& Gabriel, O. Olusanya (Eds). Nigeria Since Independence: The first 25 Years Vol.5, (80-105), Ibadan: Heinemann Educational Books Nigeria Ltd.

xxiii. Nzomo, M. (1994). The impact of the women's decade on policies, programmes andempowerment of women in Kenya, Issue 17 (2) 9-17.

xxiv. Ofong, I. (2002) Women's participation in politics in Nigeria. A paper presented at the $8^{\text {th }}$ International Women's World Congress, Kampala Uganda

xxv. Ogbogu, C. O (2012). The Role of women in politics and in the sustenance of democracy inNigeria.International Journal of Business and Social Sciences, Vol.3 (18) Special Issue.

xxvi. Ojo, E.O. (2006). Challenges of Sustainable Democracy in Nigeria, Ibadan: John Archers(Publishers) Ltd.

xxvii. Okoosi-Simbine,A.T (2007). Women marginalization and politics in Nigeria: A Review Essay in

xxviii. Albert. I.O., Derrick Marco \& Victor Adetula(Eds). Perspectives on the 2003 Elections in Nigeria: A Special Edition of IDASA Conflict Tracking Dossier.(pp92-114)Abuja: Idasa-Nigeria.

xxix. Okojo, K. (1983). Sex roles in Nigerian politics. InOppongC. (Ed.) Female and Male in WestAfrica. Boston (pp 152167)George Allen and Unwin.

xxx. Olutayo,M.S.A. (2010). Gender political participation and the feminization of poverty. IbadanJournal of the Social Sciences, Vol.8(2). 46-61.

xxxi. Onyeji , E. ( 2019).2019 Elections worst for Nigerian women in nearly two decades,

xxxii. Analysis shows. In premium times online newspaper Abuja-visited April 23.www.premiumtimeng.com/news

xxxiii. Pogoson, A.I. (2013).Women participation in the electoral process: the Nigerianexperience. The Nigerian Electoral Journal: Genderand the Electoral Process Special Issue Vol.5. (1).1-34.

xxxiv. This Day Newspaper (2007). Editorial comments on Sunday. ThisDay Newspaper. December,6 pp 3

xxxv. Udegbe, I.B.1998).Gender and Leadership: Images and Reality. Faculty of Social SciencesLectures University of Ibadan.Ibadan Vintage Publishers. 